\title{
Participants' motivations to contribute to biodiversity citizen science projects
}

The public participation in scientific projects (citizen science) is significantly increasing specially with technology developments in recent years. Volunteers play an essential role in citizen science projects, therefore understanding their motivations, and understanding how to sustain them to keep contributing to the project are of utmost importance. This paper presents the analysis of volunteers' characteristics and their motivations to contribute to a citizen science project, which aims at encouraging citizens to take action for biodiversity. The results from the online survey illustrate that people are more motivated by intrinsic nature-related motives rather than extrinsic motivations. 


\section{Participants' motivations to contribute to biodiversity citizen science projects}

Maryam Lotfian ${ }^{1}$, Jens Ingensand ${ }^{1}$, Olivier Ertz ${ }^{2}$, Sarah Composto ${ }^{1}$, Mathias Oberson ${ }^{2}$, Simon Oulevay $^{2}$, David Campisi ${ }^{2}$, and Florent Joerin ${ }^{3}$

${ }^{1}$ University of Applied Sciences and Arts Western Switzerland, School of Business and Engineering Vaud, Insit Institute, Yverdon-les-Bains Switzerland

${ }^{2}$ University of Applied Sciences and Arts Western Switzerland, Media Engineering Institute, Yverdon-les-Bains Switzerland

${ }^{3}$ Faculty of Geosciences and Environment, UNIL, University of Lausanne, Lausanne, Switzerland

Corresponding authors:

Maryam Lotfian ${ }^{1}$, Jens Ingensand ${ }^{1}$

Email address: \{maryam.lotfian, jens.ingensand\} @heig-vd.ch

\section{ABSTRACT}

The public participation in scientific projects (citizen science) is significantly increasing specially with technology developments in recent years. Volunteers play an essential role in citizen science projects, therefore understanding their motivations, and understanding how to sustain them to keep contributing to the project are of utmost importance. This paper presents the analysis of volunteers' characteristics and their motivations to contribute to a citizen science project, which aims at encouraging citizens to take action for biodiversity. The results from the online survey illustrate that people are more motivated by intrinsic nature-related motives rather than extrinsic motivations.

Keywords: Citizen Science, Motivations, Questionnaire, Biodiversity, Mobile Application

\section{Introduction}

With the development of technology in recent years, the contribution of non-professionals in scientific projects, a term known as Citizen Science (CS), is significantly increasing (Chandler et al., 2017). Volunteers assist the scientists to collect data, which are excessively costly or difficult to acquire. Accordingly, the two main components of each citizen science project are data and the volunteers. There is a large number of studies addressing the quality of data collected by volunteers (Wiggins et al., 2011) (Crall et al., 2011) (Flanagin and Metzger, 2008), however, there are not as much researches concerned about volunteers themselves. Therefore, it is essential to understand how to attract volunteers to contribute to CS projects, what their motivations are, and how to sustain them to keep contributing to the project.

The objective of this paper is to analyze volunteers' demographics, and their motivations to contribute to our biodiversity CS project called "Biopocket". Biopocket is a mobile application, which aims at increasing citizens’ awareness and knowledge about biodiversity, as well as encouraging them to take actions in favor of it. In order to understand volunteers' motivations to contribute to Biopocket, an online questionnaire has been designed.

In the following sections, we are first presenting different participation levels, and various types of motivational factors to contribute to CS projects. Afterwards we will discuss about the 
structure of our questionnaire, followed by results and statistical analysis of the answers from our respondents. Finally, we will present the discussions and future work.

\section{Motivations}

\subsection{Who are the volunteers?}

To understand the motivations of volunteers to contribute to CS projects, it is important to know how to categorize the volunteers with respect to their level of engagement and their knowledge of the project. Muki Haklay (Haklay, 2011) has defined a framework to categorize volunteers based on their level of participation (Figure 1). He has defined four categories, which go from first level where citizens contribute only as data collectors or sensors to the highest level, called "Extreme CS", where they are involved in the project as scientific collaborators (Level 4).

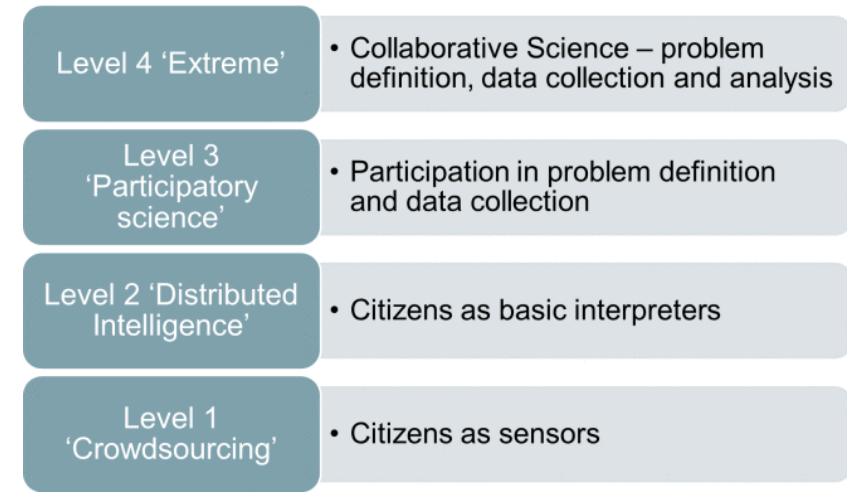

Figure 1: Levels of Citizen Science Participation (Haklay, 2011)

The motivations vary depending on the participation levels. For instance, people who are contributing as sensors or data collectors need strong motivations such as a monetary reward to contribute to the project. However, people who are contributing to different stages of the project from problem definition to data collection and analysis of the results, usually participate due to their strong interest in the topic of the project and not for receiving something in return.

Besides the participation level framework defined by Muki Haklay, Preece and Shneiderman (Preece and Schneiderman, 2009) have introduced a framework called "Reader-to-Leader", which aims at motivating social participation in online communities. This framework shows the evolution of users' participation in online social communities from reader, to contributor, to collaborator, and to leader (Figure 2).

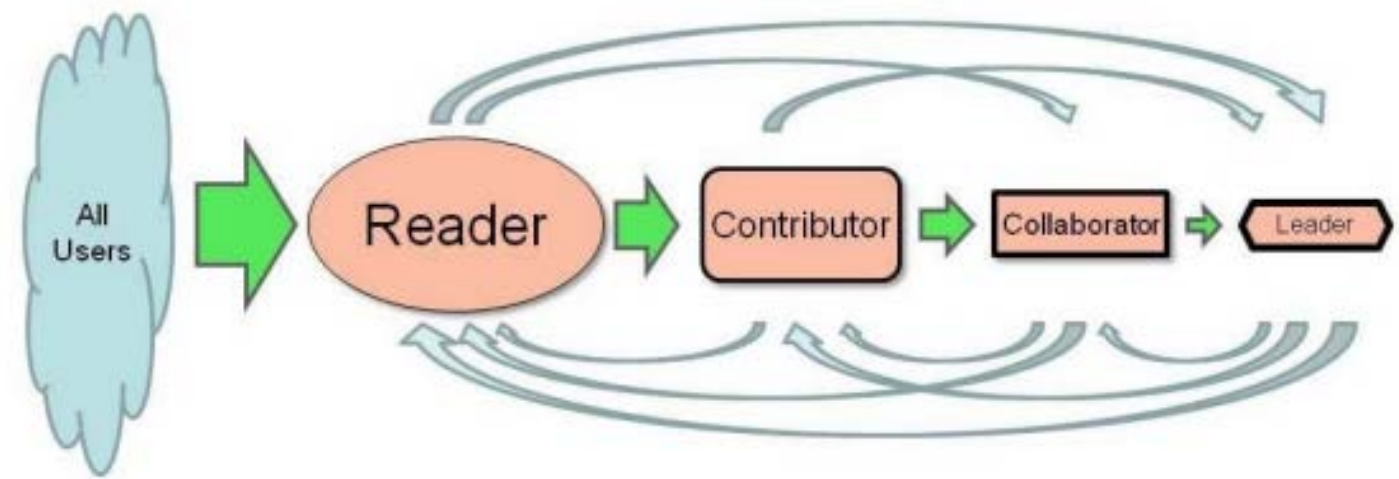

Figure 2: The Reader-To-Leader Framework (Preece and Schneiderman, 2009) 
Inspired by the two latter frameworks, we have defined a typology for the participants of our Biopocket project. This categorization considers the activities of participants for biodiversity and their degree of utilization of the Biopocket mobile application. Action levels range from citizens with no information about biodiversity (N0), to citizens doing very important activities in favor of biodiversity and encouraging others as well to take action (N3). Moreover, utilization levels goes form not knowing about the application (N0) to being a very active contributor to the application (N3). Therefore, in order to level up the citizens from $\mathrm{N}_{n} \mathrm{~N}_{\mathrm{m}}$ to $\mathrm{N}_{\mathrm{n}+1} \mathrm{~N}_{\mathrm{m}+1}(0<=$ $\mathrm{n} \& \mathrm{~m}<3$ and n: utilization; m: action) we need to understand what their motivations are.

Table 1: Measuring Success for Biopocket mobile application

\begin{tabular}{|l|c|c|c|c|}
\hline & $\begin{array}{c}\text { Action } \\
\text { level 0 }\end{array}$ & $\begin{array}{l}\text { Action } \\
\text { level 1 }\end{array}$ & $\begin{array}{l}\text { Action } \\
\text { level 2 }\end{array}$ & $\begin{array}{c}\text { Action } \\
\text { level 3 }\end{array}$ \\
\hline $\begin{array}{l}\text { Utilization } \\
\text { level 0 }\end{array}$ & $\mathrm{N} 0$ & $\mathrm{~N} 1$ & $\mathrm{~N} 2$ & $\mathrm{~N} 3$ \\
\hline $\begin{array}{l}\text { Utilization } \\
\text { level 1 }\end{array}$ & $\mathrm{N} 1$ & $\mathrm{~N} 1$ & $\mathrm{~N} 2$ & $\mathrm{~N} 3$ \\
\hline $\begin{array}{l}\text { Utilization } \\
\text { level 2 }\end{array}$ & $\mathrm{N} 2$ & $\mathrm{~N} 2$ & $\mathrm{~N} 2$ & $\mathrm{~N} 3$ \\
\hline $\begin{array}{l}\text { Utilization } \\
\text { level 3 }\end{array}$ & $\mathrm{N} 3$ & $\mathrm{~N} 3$ & $\mathrm{~N} 3$ & $\mathrm{~N} 3$ \\
\hline
\end{tabular}

\subsection{What are volunteers' motivations?}

Depending on the knowledge and participation level of citizens, there are various types of motivations to contribute to CS projects. Budhathoki and Haythornthwaite (Budhathoki and Haythornthwaite, 2012) have defined a very comprehensive list pf motivational factors for volunteers to contribute to Volunteered Geographic Information (VGI) projects. They have categorized the motivational factors into intrinsic and extrinsic motives. Table below shows the summarized motivational factors defined by them: 
Table 2: Intrinsic and Extrinsic motivations (Budhathoki and Haythornthwaite, 2012)

\begin{tabular}{|l|l|}
\hline & Unique ethos \\
& Learning \\
& Personal enrichment \\
& Self-actualization \\
& Self-image \\
\hline \multirow{3}{*}{ Intrinsic Motivations } & Fun \\
& Recreation \\
& Instrumentality \\
& Self-efficacy \\
& Meeting own needs \\
& Freedom of expression \\
& Altruism \\
\hline \multirow{5}{*}{ Extrinsic Motivations } & Career \\
& Strengthen social relations \\
& Project goal \\
& Community \\
& Identity \\
& Reputation \\
& Monetary return \\
& Reciprocity \\
& System trust \\
& Networking \\
& Socio-political \\
\hline
\end{tabular}

\section{BioPocket}

Biopocket is a mobile application, with the objective of encouraging citizens to learn about biodiversity and to take action towards it. The application is free, and is being developed using the open-source development framework, Apache Cordova (https://cordova.apache.org/). A set of biodiversity actions have been defined by the environmental scientists working on the project. The actions are classified according to several criteria such as theme, complexity, importance, etc. For instance, the actions can vary from very simple such as observation of species to more complex like building a place for birds, or creating a pond in your garden. An interactive map is available in the application, which helps the users to see the actions that are being taken in their neighborhood. The user can select an action and follow the instructions given in the application on how to do the action or what materials is required for each specific action. The application is still under development, but in order to evaluate who are our potential users and what would be their motivations to contribute to Biopocket, an online survey has been designed. The results from the questionnaire helps us to define initial hypothesis about the characteristics of our future users, and once we have the working protocol, we can check if the hypothesis are in fact correct or not. Therefore, the main two key questions we are planning to address here are:

1) What is the socio-demographic background of the respondents?

2) What are their motivations to take action in favor of biodiversity?

\section{Online questionnaire design}

In order to answer the above research questions, the online questionnaire was designed in Google Form. The questionnaire consists of 20 questions with various categories: volunteers' background on environmental activities, their motivations to contribute to Biopocket or in general taking action to promote biodiversity, their views on mobile technology (location access authorization, creating a user account, etc.), and their demographic information (age, gender, 
education, occupation, etc.). In addition, in order to do spatial analysis, people were asked for their postal codes. The questionnaire was combined of different question types included ranking, multiple choice questions, and 4-point Likert scale questions (ranged from 1 strongly disagree to 4 strongly agree). The question regarding motivations was a combination of intrinsic and extrinsic motives adapted from the motivational factors introduced by Budhathoki and Haythornthwaite (Budhathoki and Haythornthwaite, 2012). The respondents were asked to rank their motivations from 1 highest motivation to 8 lowest motivation. The preliminary version of the questionnaire was piloted among the students from the GIS class at the University of Applied Science Western Switzerland, and afterwards the questionnaire link was distributed through social media posts and direct emails.

\section{Results}

\subsection{Participants' background}

Until now, 74 answers have been collected, among which 4 people have zip codes from France, so except for the spatial analysis, their answers were considered for all the other statistical analysis. The statistical analysis has been done in RStudio, a free and open-source development environment for R. The majority of respondents were in age groups 15-24 and 25-34 with $48.6 \%$ and $37.8 \%$ respectively. Moreover, the percentage of male respondents was nearly $24 \%$ higher compared to the female respondents. Students with 58\% were the largest group of respondents, and thereafter full-time and part-time employees with 23\% and 13\% respectively. In terms of education, since most of the respondents were students, slightly more than half of the respondents were in secondary education level (54\%), followed by bachelor degree with $27 \%$ and postgraduate degrees with $19 \%$. Finally, to understand the spatial distribution of the respondents, they were asked for their zip codes. Figure 3 shows the spatial distribution of respondents in Switzerland based on cantons.

Before asking the participants regarding their motivations, they were asked if they have done any actions in favor of biodiversity, and if they think individuals can help promoting the biodiversity. The result indicates that $77 \%$ of respondents have already done some actions in favor of biodiversity, and $92 \%$ of participants believe that individuals are capable of helping the biodiversity. 
Table 3: Respondents' socio-demographic information

\begin{tabular}{l|l}
\hline AGE & \\
$15-24$ & $48.65 \%$ \\
$25-34$ & $37.84 \%$ \\
$35-44$ & $8.1 \%$ \\
$45-54$ & $1.35 \%$ \\
$55-64$ & $4.06 \%$ \\
EDUCATION & \\
SECONDARY SCOOL & $54.05 \%$ \\
BACHELOR & $27.02 \%$ \\
POST GRADUATE (MASTER/ DOCTORAE) & $18.93 \%$ \\
& \\
GENDER & \\
MALE & $62.16 \%$ \\
FEMALE & $37.84 \%$ \\
OCCUPATION & \\
STUDENT & $58.10 \%$ \\
FULL-TIME EMPLOYEE & $22.97 \%$ \\
PART-TIME EMPLOYEE & $13.51 \%$ \\
OTHERS & $5.42 \%$ \\
& \\
HOUSE TYPE & \\
APARTMENT & $63.51 \%$ \\
VILLA & $25.67 \%$ \\
SEMI-DETACHED HOUSE & $8.10 \%$ \\
OTHERS & $2.72 \%$ \\
& \\
&
\end{tabular}

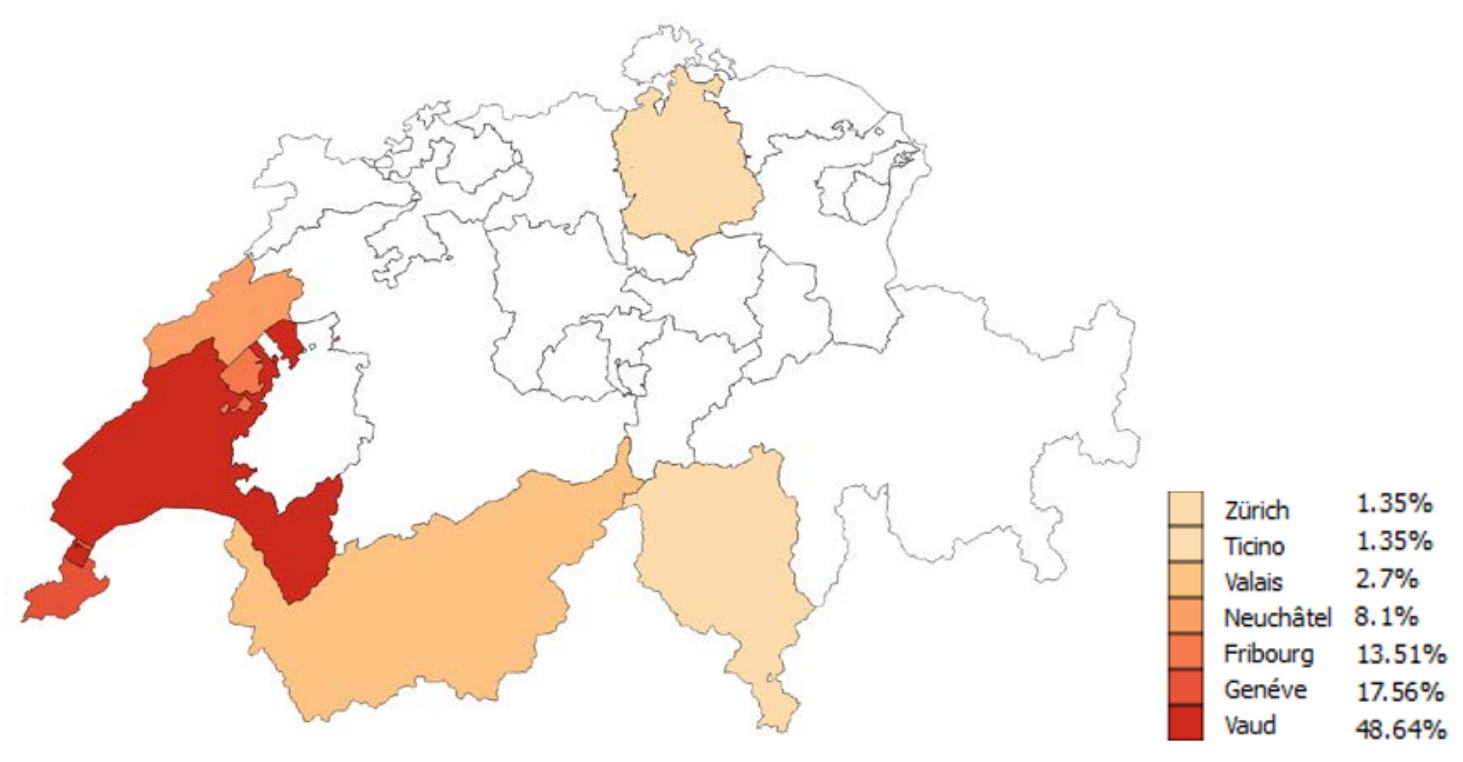

Figure 3: Spatial distribution of respondents

\subsection{Motivations}

As mentioned before, the respondents were asked to rank their motivations from 1 to 8 . Afterwards the rankings were converted to scores based on the ranks given to each motivation (from 8 points for the first rank to 1 point for the last rank). Figure 4 indicates the results of motivation ranking according to the average points given to each motivation. It is easily noticeable that the nature related motivations have the top ranks compared to other motivations. The top three motivations are "spending time in the nature", "helping the nature", and "learning about biodiversity" respectively. However, extrinsic motivation such as "receiving a monetary reward or certificate" is being ranked as the last motivation. 


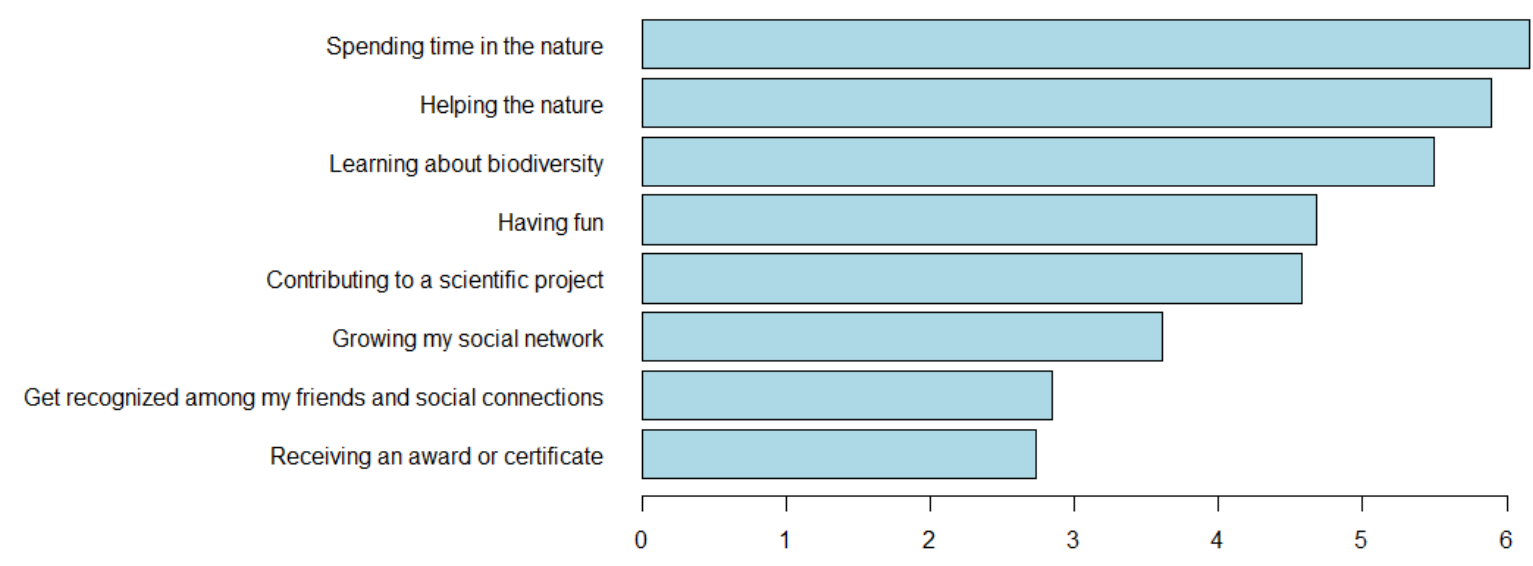

Figure 4: Motivation ranking scale

\subsection{Correlational analysis}

In addition to descriptive statistics explained in the first part of the results section, in order to analyze the correlation between the motivations and ordinal variables (age and education), the Polyserial correlation was used. To do so, we used "hetcor" function from "Polycor" package in R. Table 4 illustrates the correlation between the motivations versus age and education. According to Cohen's table of effect size (Cohen, 1992), the highlighted cells show medium correlation between the variables. However, to analyze the association between ordinal and nominal variables we used the Freeman's theta coefficient (Buck and Finner, 1985). This coefficient ranges from 0 to 1 , where 1 indicates a perfect association between the variables, while 0 indicates no association. Therefore, we analyzed the association between the motivations, and other socio-demographical variables using the "freemanTheta" function in "rcompanion" package, and the results have been shown in Table 5. The association between residence type and the motivation "getting recognized among others" explains an interesting point that people can be motivated to contribute to the project if their neighbors are participating.

Table 4: Correlation between motivations versus age and education (highlighted cells are effect size $>0.20$, *** $P$-values $<0.001 ; * * P$-values $<0.01$; $* P$-values $<0.05$ )

\begin{tabular}{|c|c|c|c|c|c|c|c|c|}
\hline & $\begin{array}{l}\text { HELPING } \\
\text { BIODIVERSITY }\end{array}$ & $\begin{array}{l}\text { LEARNING } \\
\text { ABOUT } \\
\text { BIODIVERSITY }\end{array}$ & $\begin{array}{l}\text { SPENDING } \\
\text { TIME IN } \\
\text { THE } \\
\text { NATURE }\end{array}$ & $\begin{array}{l}\text { CONTRIBUTING } \\
\text { TO A SCIENTIFIC } \\
\text { PROJECT }\end{array}$ & $\begin{array}{l}\text { HAVING } \\
\text { FUN }\end{array}$ & $\begin{array}{l}\text { GROWING } \\
\text { SOCIAL } \\
\text { NETWORK }\end{array}$ & $\begin{array}{l}\text { GETTING } \\
\text { RECOGNIZED } \\
\text { AMONG } \\
\text { OTHERS }\end{array}$ & $\begin{array}{l}\text { RECEIVING } \\
\text { AN AWARD } \\
\text { OR } \\
\text { CERTIFICATE }\end{array}$ \\
\hline AGE & $0.22 *$ & 0.11 & 0.07 & -0.14 & -0.02 & -0.05 & $-0.04 * *$ & $-0.18^{* *}$ \\
\hline EDUCATION & $0.21^{* *}$ & 0.08 & $0.24^{*}$ & -0.07 & -0.06 & $-0.13^{* *}$ & $-0.12^{* * *}$ & $-0.17^{* * * *}$ \\
\hline
\end{tabular}


NOT PEER-REVIEWED

Table 5: Association between motivations versus Residence type, occupation, and age

\begin{tabular}{|c|c|c|c|c|c|c|c|c|}
\hline & $\begin{array}{l}\text { HELPING } \\
\text { BIODIVERSITY }\end{array}$ & $\begin{array}{l}\text { LEARNING } \\
\text { ABOUT } \\
\text { BIODIVERSITY }\end{array}$ & $\begin{array}{l}\text { SPENDING } \\
\text { TIME IN } \\
\text { THE } \\
\text { NATURE }\end{array}$ & $\begin{array}{l}\text { CONTRIBUTING } \\
\text { TO A SCIENTIFIC } \\
\text { PROJECT }\end{array}$ & $\begin{array}{l}\text { HAVING } \\
\text { FUN }\end{array}$ & $\begin{array}{l}\text { GROWING } \\
\text { SOCIAL } \\
\text { NETWORK }\end{array}$ & $\begin{array}{l}\text { GETTING } \\
\text { RECOGNIZED } \\
\text { AMONG } \\
\text { OTHERS }\end{array}$ & $\begin{array}{l}\text { RECEIVING } \\
\text { AN AWARD } \\
\text { OR } \\
\text { CERTIFICATE }\end{array}$ \\
\hline $\begin{array}{l}\text { RESIDENCE } \\
\text { TYPE }\end{array}$ & 0.35 & 0.34 & 0.14 & 0.13 & 0.22 & 0.13 & 0.34 & 0.24 \\
\hline OCCUPATION & 0.20 & 0.21 & 0.20 & 0.15 & 0.13 & 0.14 & 0.06 & 0.21 \\
\hline GENDER & 0.20 & 0.13 & 0.18 & 0.05 & 0.002 & 0.09 & 0.20 & 0.15 \\
\hline
\end{tabular}

\subsection{Views on technical aspects}

We also analyzed the views of respondents regarding mobile technologies. The results indicate that the majority of respondents, nearly $72 \%$ usually will not authorize location access to the applications installed on their phone. Moreover, almost half of the survey population (mainly younger respondents) preferred to login to a new mobile application using their existing accounts such as Google or Facebook rather than registering for a new account. In addition, people were asked how they would score their level of familiarity with technology (especially mobile technology) on the scale from 1 to 10 , and the average score was 6.85 .

Table 6 shows the correlation between technical aspects versus age and education. The result shows a relatively high positive correlation between education and the level of familiarity with technology meaning that people with higher education have higher score in the scale of 1 to 10 . Moreover, it demonstrates that older respondents usually do not authorize location access to the applications installed on their phone, as well as they do not tend to use their existing accounts to login to a new application.

Table 6: Correlation between technological aspects versus age and education (highlighted cells, shows effect size $>0.3, * * * P$-values $<0.001 ; * P$-values $<0.05$ )

\begin{tabular}{|c|c|c|c|}
\hline & LOCATION AUTHORIZATION & LOGIN WITH EXISTING ACCONTS & FAMILIARTIY WITH TECHNOLOGY \\
\hline AGE & $-0.33^{* * *}$ & $-0.31^{*}$ & $0.27^{*}$ \\
\hline EDUCATION & $-0.13^{* * * *}$ & $-0.38^{*}$ & $0.50^{*}$ \\
\hline
\end{tabular}

\section{Discussions and future work}

Public participation in scientific research, is taking scientific projects to the next level, and open science is developing a deep engagement between the members of the public and scientists. Biopocket is a citizen science project with the goal of increasing citizens' knowledge regarding nature and various types of species, and guide them with their decision-makings with respect to the actions that can be done in favor of biodiversity. 
The objective of our paper was to design an online survey to understand the main motivations of people to contribute to the Biopocket project. The results obtained from this questionnaire help us to define the hypotheses regarding the behavior and characteristics of the potential future users of our application, and to check the validity of these hypotheses once we have the working protocol. Moreover, the correlations between motivations and the socio-demographics characteristics of the respondents make it easier for us to find our target users and to know how to better design our application in order to meet their requirements.

The results from the motivation-ranking section of our survey illustrated that motivations related to nature and biodiversity are the central motivations for our respondents, while extrinsic motivations such as receiving monetary incentives were ranked in average as the last motivations.

This survey is still active online, and our future objective is to analyze the responses with a larger sample size. Moreover, using the zip codes taken from respondents we are aiming to use spatial analysis, which is to classify the study area (Switzerland municipalities) to urbanrural classes and see whether living in different areas affect people's motivations.

\section{References}

Buck, J. L. and Finner, S. L. (1985) “A still further note on freeman's measure of association,” Psychometrika, 50(3), pp. 365-366. doi: 10.1007/BF02294111.

Budhathoki, N. R. and Haythornthwaite, C. (2012) "Motivation for Open Collaboration: Crowd and Community Models and the Case of OpenStreetMap.” doi: $10.1177 / 0002764212469364$.

Chandler, M. et al. (2017) "Involving Citizen Scientists in Biodiversity Observation," in Walters, M. and Scholes, R. J. (eds.) The GEO Handbook on Biodiversity Observation Networks. Cham: Springer International Publishing, pp. 211-237. doi: 10.1007/978-3-31927288-7_9.

Cohen, J. (1992) “A power primer.,” Psychological Bulletin. US: American Psychological Association, pp. 155-159. doi: 10.1037/0033-2909.112.1.155.

Crall, A. W. et al. (2011) "Assessing citizen science data quality: An invasive species case study,” Conservation Letters, 4(6), pp. 433-442. doi: 10.1111/j.1755-263X.2011.00196.x.

Flanagin, A. J. and Metzger, M. J. (2008) "The credibility of volunteered geographic information,” GeoJournal, 72(3-4), pp. 137-148. doi: 10.1007/s10708-008-9188-y.

Haklay, M. (2011) Levels of participation in citizen science and scientific knowledge production.

Preece, J. and Schneiderman, B. (2009) "The Reader-to-Leader Framework: Motivating Technology-Mediated Social Participation,” AIS Transactions on Human-Computer Interaction, 1(1), pp. 13-32. doi: 10.5121/ijfcst.2014.4403.

Wiggins, A. et al. (2011) Mechanisms for data quality and validation in citizen science, Proceedings - 7th IEEE International Conference on e-Science Workshops, eScienceW 2011. doi: 10.1109/eScienceW.2011.27. 